\title{
DE HERENIGING VAN EEN PAARD MET EEN RUITER
}

Het lopende onderzoek naar de groep grafbeelden uit de Tang-dynastie (618-907) heeft het inzicht in de wijze waarop de groep gemaakt is sterk vergroot. ${ }^{1}$ De resultaten van het onderzoek blijken ook van belang voor de manier van presenteren in de vitrine. De objecten zijn genummerd, zoals alle in de collectie opgenomen objecten: de paarden en kamelen hebben een AK-MAK-XX nummer dat eindigt op - $\mathrm{A}$, en alle zadels en ruiters eindigen op -B. De nummering geeft dus aan welk paard bij welke ruiter of zadel hoort. Zo hoort het paard AK-MAK-65-A bijvoorbeeld bij zadel AK-MAK-65-B.

Tijdens het nog steeds voortschrijdende onderzoek werd vastgesteld dat op de rug van drie van de paarden enkele strepen in bas-reliëf staan. Deze strepen zijn in de normale situatie niet zichtbaar omdat ze dan worden afgedekt door een zadel of een ruiter. Door de plaats en de vorm van de strepen staat vast dat zij tot het originele materiaal behoren en reeds voor het bakproces werden aangebracht. Visuele observatie maakte duidelijk dat zich op de onderkant van drie zadels ook strepen bevinden maar deze zijn in haut-reliëf aangebracht. Van alle gevonden strepen werden vervolgens afdrukken gemaakt. Al snel werd duidelijk dat ze een nieuw licht werpen op de samenhang tussen paard en zadel dan wel ruiter. We nemen nu aan dat deze strepen een directe markering vormen die aangeeft dat een paard specifiek bij een zadel of een ruiter hoort. Zoals op de foto duidelijk te zien is, sluiten twee van de markeringen naadloos op elkaar (afb. 1).

Afb. 1

Afdrukken van de strepen.

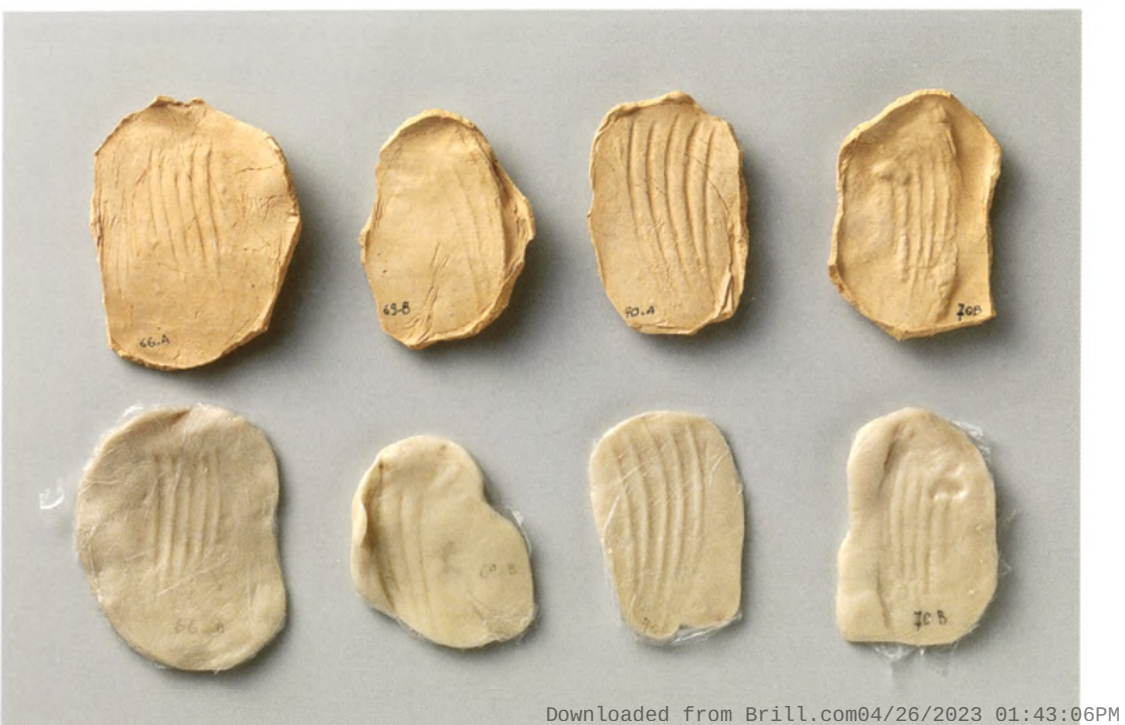

Downloaded from Brill.com@4/26/2023 01:43:06PM 


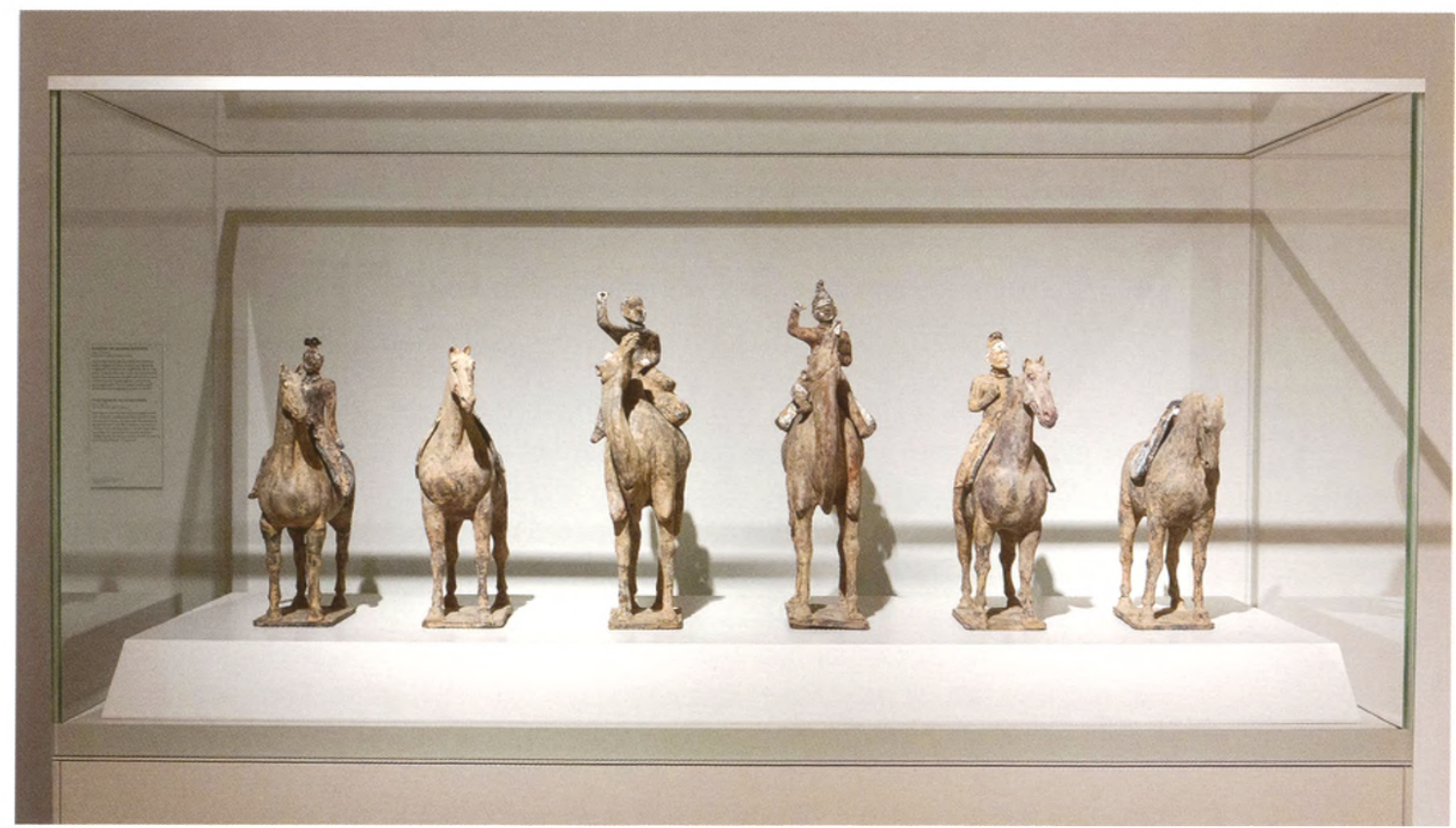

Afb. 2

V.I.n.r.:

AK-MAK-66-A en AK-MAK-69-B; AK-MAK-65-A en -B; AK-MAK-67-A en -B; AK-MAK-68-A en -B; AK-MAK-7O-A en -B; AK-MAK-69-A en AK-MAK-66-B.
De AK-MAK-nummering van deze twee onderdelen komt echter niet overeen: Het strepenpatroon van paard AK-MAK-69-A en ruiter AK-MAK-69-B kloppen niet met elkaar. Qua vorm en positie passen de strepen van ruiter AK-MAK-69-B echter wel exact bij die van het paard AK-MAK-66-A. Ook passen de strepen van zadel AK-MAK-66-B exact bij die van paard AK-MAK-69-A.

Er is maar één conclusie mogelijk: ze horen bij elkaar. In de nieuwe opstelling werden ruiter en zadel dan ook met het bijbehorende paard herenigd. (afb. 2)

- Isabelle Garachon is sinds 1989 hoofd van het restauratieatelier keramiek, glas en steen in het Rijksmuseum Amsterdam.

- Lucien van Valen is sinoloog en schilder. Zij heeft zich gespecialiseerd in het onderzoek van techniek en materiaal van Chinese kunst.

\section{Literatuur}

Isabelle Garachon en Lucien van Valen, 'De restauratieateliers: Gewapende paarden en kamelen', Aziatische Kunst 42/3 2012, pp. 15-24.

\section{Noot}

1. Garachon en Van Valen 2012: 15-24. 